\title{
Play for Two Voices: On Translating the Poetry of Anja Utler
}

\author{
Kurt Beals, \\ University of California (Berkeley)
}

I (KB, translation theorist) recently sat down with Kurt Beals $(\mathrm{KB}$, translator) in the kitchen of his California home and, over a cup of coffee, asked him some questions about his translation of münden - entzüngeln, a book of poems by the German-born, Vienna-based poet Anja Utler.

KB: Let's start with the question of motivation: What was it about Anja Utler's work that made you, as a translator, want to take it on? Did you do it for the money, or the fame, or was there something else?

KB: As much as I'd love to say that I was drawn to Utler's work by visions of honor and glory, I think what really pulled me in was the syntax. The first time I read her poems, I knew that was something I hadn't seen before. She often uses punctuation to interrupt a sentence at what seems like the least likely point between a preposition and its object, for example; she uses certain German structures like reflexive verbs and separable prefixes in unorthodox ways that open up new meanings; and often the grammatical subject of the sentence disappears entirely. You can infer a pronoun here and there, but more often you're left with a conspicuous absence, with verbs floating free in the poems, not quite attached to subjects or objects. For instance, the poem that begins the first cycle in the book (see Appendix A) does without subjects entirely - something that's very unusual in German, to say the least.

Then, on a semantic level, there's an intertwining of different sets of words and images - she combines descriptions of a "natural" world (I put that in quotes because her rivers and trees and mountains are interrupted by mining, excavation, human interventions of various kinds) with images of human anatomy, particularly parts of the body involved in the production or perception of sound and speech, in such a way that the various domains become indistinguishable. For instance, the word "kiefer" that turns up repeatedly means both jaw (der Kiefer) and pine tree (die Kiefer) - and in these poems it generally means both at once, not one or the other.

So in short, it's a challenge, and that was enough to make me want to spend 
more time with these poems.

KB: Does it matter to you that Utler is, in this country at least, a relatively unknown and untranslated poet? Is there a difference between translating a more or less obscure poet and translating someone who is already recognized?

KB: I think it certainly makes a difference. If I had decided to re-translate a wellknown poem by Goethe, or Rilke, or Celan, I would have been dealing with a very different set of considerations. I would have had other translations to look at, either as models or as warnings, and readers who don't know German would have had the opportunity to compare my translation to other translations and decide for themselves which they like better, at least as an English poem.

KB: When Gayatri Spivak writes about the difference in reception between her translations of Mahasweta Devi and her translations of Jacques Derrida, she says "In my translations of Devi, I have almost no fear of being accurately judged by my readership here. It makes the task more dangerous and more risky" (Spivak "Politics" 378). Can you identify with that? What's the risk, if you aren't being judged?

KB: I think part of what she's referring to is the risk of having too much control over the way that a writer is read or perceived; that's at play to some degree for me in translating Utler too, although more English-language readers may have access to German poetry than to Bengali literature. Some individual cycles from münden - entzüngeln have been translated into English and are available online, and Rosmarie Waldrop recently translated one cycle for an anthology, but no one has taken on the whole book, so in some cases my translations will be the only ones available in English. One of the greatest challenges is that Utler's work requires constant re-invention to represent all of the wordplay, the alliteration, the innovations with unusual structures, and no single translator is likely to come up with the best solution to every puzzle. I can do my best, but there will always be passages in the book where what I come up with just doesn't communicate what Utler was doing.

KB: So, the risk is that your translation won't show the English-language reader what's so great about this unknown poet?

That's part of it. But the problem isn't limited to under-representing the writer in 
translation - I think there's a risk of over-representing, too. Especially in the case of a relatively unknown writer, the translator can slip into the role of advocate, which can be a good thing for the sake of introducing people to that writer, but it also means that I (the translator) am representing the writer I want to be translating, not just the writer I am translating. I've seen that in the way I talk to colleagues about my translation project - what do I choose to tell them about Utler's writing, what impresses me the most, and how do I convey that? These issues can have an impact on the final product of the translation process. If I'm struck by the way that Utler uses a particular word (say, "kiefer"), I'm going to spend more time trying to come up with an interesting translation that captures both meanings. And there's a risk that I'll be so eager to have other people see how brilliantly she uses these polysemous words that I'll overdo it, and the double meanings in English will be too obvious. Whereas if I were translating Celan, I could expect a certain familiarity with his neologisms and what he does with language, so I might feel less need to push it on the reader.

KB: This sounds like what André Lefevere is talking about when he writes about differences between various Brecht translations - "Manheim can afford to be good because Hays, and especially Bently, translated Brecht before he did. They focused attention on Brecht and, in so doing, they got the debate going. If they had translated Brecht on his own terms to begin with, disregarding the poetics of the receiving system, chances are that the debate would never have got going in the first place" (Lefevere 249).

$\mathrm{KB}$ : It's true that one tendency of the translator-as-advocate might be to accommodate the work to the expectations or poetics of the receiving system. But in Utler's case, it's really her distinctive poetics that stands out to me the most, and that I think will stand out to English-language readers, too, if it comes across in the translation. Which is not to downplay the importance of Brecht's poetics, it's just that in Brecht's case it may be more feasible to take elements like plot, or characters, and embed them in a different poetics - you'll end up with a different play, certainly, but it's conceivable that it will be something that could be accepted as a drama in its own right, within an American system. Whereas with Utler, I can't imagine how her work could be accommodated to the poetics of another receiving system, in Lefevere's sense. As I said at the beginning, one almost enters her poems through the syntax. If English-language readers are going to take an interest in Utler's work, I think it will be because a translator manages to re-create some of that distinctive syntax in English and to convey its 
unique place in her overall poetics, not because someone figures out how to make her sound like Billy Collins.

KB: It sounds to me like you're slipping into your advocate or interpreter role, arguing for a privileging of poetics in Utler's case in particular.

KB: I'm sure that does reflect some of my own biases, or my own poetic tastes. As a translator, at least, I'm drawn to the challenge of a syntactically innovative writer. So it could well be that my reading of Utler is influenced by, say, $\mathrm{L}=\mathrm{A}=\mathrm{N}=\mathrm{G}=\mathrm{U}=\mathrm{A}=\mathrm{G}=\mathrm{E}$ poets, and by certain other poets you could call, for lack of a better word, "experimental"; if you read her that way, you could connect her to other contemporary poets writing in German like Ulf Stolterfoht, whose "fachsprachen" also test the limits of language, though I think the nature of his experimentalism is quite different from Utler's. You could equally well approach her as a nature poet, for example, and read her in the context of someone like Hopkins, or read her in or against the tradition of German nature poetry. Then again, Utler has a PhD in Slavic Literature, she wrote her dissertation on gender in the work of four Russian women poets of the $19^{\text {th }}$ and $20^{\text {th }}$ centuries, so you could read her work in the context of Russian poetry, or of other women poets and I suspect you would come up with a different translation each time, because different aspects of her poetry would stand out.

KB: What role does language itself ultimately play in all of this? There's a tendency in translation theory to focus on translation as an interaction that occurs, not just between two texts or between two people, but between two languages - Benjamin deals with this in "The Task of the Translator," as I'm sure you know. There's the question of whether to distort the syntax in the socalled target language to imitate that of the source language; and of course there's the inevitable recognition that the target language just can't do everything that the source language does. How does all this play out in translating a poet like Utler?

KB: I'll start with Benjamin, though I'm sure I won't finish with him. For the longest time I was frustrated that his translation essay was required reading in every translation class I ever took, because I couldn't see how that essay could possibly be useful to a practicing translator. It seemed so remote from the practical questions that face a translator - how did he manage to write the introduction to a volume of translations of Baudelaire without mentioning 
Baudelaire himself or the challenges posed by his particular work even once? But translating Utler actually shed some light on Benjamin for me.

His emphasis on the significance of how something is meant rather than what is meant, and his emphasis on syntax, have frequently played into my thinking - at least when I'm pausing between lines and thinking about what to do next, if not necessarily when I'm actually trying to choose the right words. What seems most relevant to me in these observations is the difference Benjamin sees between the intention of the original, which relates to a particular object or context, and the intention of the translation, which relates to the language as such. He argues that the translation never intends the same thing as the original, and this seems right to me, at least insofar as what I'm thinking about when I try to choose the right words is, first and foremost, Utler's poem, not the river or mountain or mouth that she had in mind - in other words, I'm considering the possibilities of language with respect to language, not with respect to extralinguistic referents, and I think that's part of what Benjamin is saying, if I understand him correctly. That's in contrast to, say, the way I would approach the translation of an informational brochure for arthritis patients, which I've also done, with somewhat lesser artistic and greater financial rewards. If I see the word "Kiefer" there, clearly I'm not going to think of a pine tree. I'll think of a jaw and use the English word that corresponds to it.

I think this is what Benjamin means when he says "The lower the quality and distinction of its language, the greater the extent to which it is information, the less fertile a field it is for translation," whereas "The higher the level of a work, the more it remains translatable even if its meaning is touched upon only fleetingly" (Benjamin 262). Interestingly, he reverses the terms normally used to speak of translatability. What's translatable turns out to be exactly what doesn't have literal equivalence.

KB: Benjamin concludes by positing "the interlinear version of the Scriptures" as "the prototype or ideal of all translation." This seems to suggest a close syntactical adherence to the original, whatever that original might be. On a similar note, Spivak refers to Derrida's demand that one focus on "not the general laws of the language, but the laws specific to this text" (Spivak "Translating" 508). How does this syntactic adherence come across in your translations of Utler? 
KB: Certainly it comes through in one way or another, but the question for me is whether to stick close to the peculiarities of German syntax or to seek equivalent structures in English that may be quite different in their concrete form. On the one hand, a real interlinear translation that sticks too close to German grammar might just come out sounding like a Teutonic parody. But what the quote from Spivak suggests is that you have to look at what the author is doing with the language, in what ways this text deviates from standard usage, how the author takes the means at her disposal in the language and uses them to create her work.

Take the lines from the first poem: "ja wieder und wieder ent-/wrungen sich...": "entwrungen" is a very unusual form that, based on its components, would suggest the act of wringing something out of something else - e.g. to wring water out of a towel. In this case, I did decide to render Utler's invention "entwrungen" with a prefix in English, "un-/wrung," to maintain some of the strangeness. Elsewhere I've sometimes used structures more typical of English, like phrasal verbs, but here it seemed that a phrase like "wrung out" would be too familiar, too conventional in English. To that extent, I've "Germanized" the syntax of the English translation somewhat. I think some "foreignization" of this kind is appropriate, insofar as Utler's poems often "foreignize" German itself, whether by using unusual words, by inserting technical terms into a poetic context, or by foregrounding particular forms, e.g. prefixes. Using the phrase "wrung out" would be too domesticating in this case: it would make the poem less unusual and unsettling in English than it is in the original German.

On the other hand, just after "ent-/wrungen" we have the reflexive pronoun "sich": there's a suggestion that two or more things are "unwringing" themselves from each other. The "sich" comes up in many other poems in the collection too, sometimes with a sense of reciprocity, sometimes reflexivity, but frequently paired with verbs that aren't reflexive in standard usage. One reason it works in German is that the third-person reflexive pronoun in German is the same for all genders, and for both singular and plural - it's one word that means "oneself/himself/herself/itself/themselves," depending on context, so it can suggest a subject without one actually being present. Whereas if you were to translate "sich" every time it occurs with an English "oneself/himself/herself/itself/themselves," you'd end up not only with a rhythmic monstrosity, but also with a level of specificity that isn't there in the original. In cases like that you can't just reproduce the German syntax one-to- 
one. As you can see, here I've translated "ent-/wrungen sich" as "un-/wrung from each," hoping that suggestion of "each other" will come through.

\section{KB: Have you read Samuel Weber's essay on the "Task of the Translator"?}

KB: I'm afraid not.

KB: I'm not sure that I believe you. In any case, Weber sees Benjamin arguing that translation is a movement "Not simply back to the original or to the origin, but rather away from it" (Weber 75).

$\mathrm{KB}$ : That certainly rings true to me, particularly when it comes to translating more experimental poetry. The most exciting moments for me in translating Utler's work were moments when I discovered new possibilities in English that were suggested, but not dictated, by the German - sometimes a word like "spit" or "sap" or "stem" would fit in at just the right place, with geographical, botanical, and anatomical meanings all working together.

For example, the third poem of the cycle (see Appendix A) is full of images of networks, weaving together, spinning, sometimes contained as secondary meanings that can't be conveyed in English by a word-for-word translation. The German "netzhaut" translates literally as "retina," but it contains the words for network (Netz) and skin (Haut). As a matter of fact, "net" is there in the Latin root of "retina" as well, but it certainly isn't as evident. I was frustrated to lose this resonance, but then I came to the phrase "du ragst" a few lines later. This could be translated as "you tower" or "you protrude," but when I hit on "you loom," all the meanings fell into place. That's just one instance, but there were a number of latent possibilities in English that I came across because I was trying to figure out how to match Utler's own innovations - so in that sense, I think you could certainly say that the translation led away from the original and into some new possibilities in English.

KB: Weber also says something that might relate to Utler's disruption of German syntax in her poems: “translation 'moves' only by arresting movement. By reproducing the syntactic arrangement of words from one language to another according to the precept of 'syntactic literalness,' the movement of translation disrupts the grammatical rules that create meaning and institutes in their stead a sequence that does not add up to a whole" 


\section{(Weber 76).}

Weber apparently means it with reference to Benjamin's idea that imposing the syntax of one language onto another will force the recipient language to realize more of its own possibilities. But this idea overlaps, I think, with what Utler herself is doing in her poems. By breaking up words or disrupting standard German syntax - "arresting movement," as Weber says - she open up new fields of meaning or intersections, initiating a movement away from the source, so to speak, to explore new possibilities.

\section{KB: But isn't there also a risk, as a translator, of moving too far away from the source?}

I've been very fortunate to work with the source herself - that is to say, not the text, but the author - and her help has been invaluable. She's answered all of the questions I had about obscure words, and she went through my translations and offered comments on a number of word choices, which I've tried to take into account in my revisions. For example, the words "mit gehangen" turn up in one of her poems, and I had taken this to be a preposition followed by a noun that doesn't quite exist in this form, but could - it seemed to suggest the participle "hanged," as well as "gehängen," which could be a garland, a declivity, a particular kind of root network... What I didn't know was that it referred to a colloquial German expression "mitgefangen, mitgehangen" - "caught together, hanged together." In cases like that, working with the author has helped me stay closer to the resonances that the text has for the author, and likely for many German readers as well.

On the other hand, there have been a few times when she's told me that my translation wasn't exactly what she meant, but she liked it anyway and thought it worked well in the poem. The question in that case, I suppose, is whether I'm justified in taking greater liberties with the text than I would on my own, because the author herself is giving me the authority. Should we be conspiring to lead the translation even further from the original?

\section{KB: If you're caught together, will you be hanged together?}

KB: Exactly. Then again, in a text like Utler's, so much of the meaning rests on polysemy, and on relations, whether logical or etymological, that happen to be 
there in German, and might not be there at all in English. So some degree of reinvention is absolutely necessary, and it certainly helps to feel that I have license to do that, that the author thinks my reinventions are consistent with her project.

Of course there's a "theorist" voice in my head that says "the meaning of the text isn't determined by the author's intention," but as a translator it certainly helps to know what she had in mind. And speaking of dialog and the theorist voice...

\section{KB: Yes...}

KB: Do you mind if I ask you why you wanted this paper to be a dialog? I'm always happy to talk about translation, but you're the theorist: can't you just write your essay without my help?

KB: No more than you can do a translation without mine. 


\title{
Appendix A: Translations
}

\author{
I \\ ja, wieder und wieder ent- \\ wrungen sich, immer, bloß \\ bin murmeln bin: wie \\ versehrt werden, roh \\ unterm flimmerhaar, \\ roh \\ I \\ so, over and over un- \\ wrung from each, always, bare \\ am murmur am: as \\ to grow wounded, raw \\ under cilia, \\ raw \\ II \\ - vernehmen: nur an den schürfstellen: ausgelöst \\ zerfurchen - $\quad$ stehen, spüren, drifte schon: schlingre dir zu \\ durchs: zerklüftete höre - du sprichst mir vom \\ abraum, den halden vom: aufpflanzen, \\ windrose, -rad vom: rotieren sprichst, glänzendes \\ rotorblatt sagst du - es: schlingert, ja, schlingre, wie \\ arm, flügel pflügt: sich den rücken, ja, furcht \\ durch die erdrauch- die taubnesselfelder \\ und stumpft: erst am schulterblatt ab \\ II \\ - perceive: but at the opencuts: outbroken \\ enfurrow - $\quad$ standing, sensing, drift now am: pitching to you \\ through the: fissured am hearing - you speak to me of over- \\ burden, of scree of: implanting, the \\ windrose, -wheel speak of: rotating, glistening \\ rotor blade you say - it: pitches, now, pitch, as a \\ veined arm, a wing plows: its back, engraves furrows \\ through the earth-smoke the dead nettle fields \\ and at last: on the shoulder blade dulls down \\ III
}

(C) Copyrights TranscUlturAl \& Author (2009) 
- lösen: sich eingraben -

- disentangle: engrave -

- entgegen: entrinnen -

- encounter: wie ins wuchernde: einfinden wollen

sich: haspeln, entgegen, sich: auflegen,

-fiedern wie: werden zur: netzhaut

für furchen für flöze und: gänzlich sich

aufspinnen, netznervig werden so

zitternd ein: gitterblick - sehe du

ragst du sprichst - sein wie

hineingewirkt, -wunden: ins

nervenstrang dickicht aus taubnessel

erdrauch; ein pochen - vergesse -

ja höre, vernehme nicht mehr

III

as wanting to enter: the wilding

to: splutter, against, to: lay up,

feather out as: to grow into: retina, netting,

for furrows for seams and: fully to

spin up, grow nervose so

trembling a: netted view - see you

loom you speak - be as

worked-, as wound-in; to the

nerve-fiber thicket of dead, of deaf nettle

earth-smoke; a throbbing - forget -

now hear, perceive no more

IV

verspüre nur: taumle, ja, murmle - ein murmelnder

bachlauf, so heißt es - nicht kennen, ja

vielmehr: entgegen zu stürzen sich schließlich

zu: rinnen zu rieseln beginnen ergießen sich

sperrende kiefer bis: tief in die niederung

- talsohle, heißt es - wie: eingeschleust sein

aus dem: speichel- ins bachbett - ent-

lastungsgerinne - entsickert, gemündet in

schlingende flutende, fransen mäandernde

adern sich aus - richtung: talsperre - jochbein, ja

gurgeln und stockt stottert fängt: sich an reusen aus

hornblatt, gezähnt, flutet im: gerodeten mund

IV

but feel only: stagger, well, murmur - a murmuring 
http://ejournals.library.ualberta.ca/index.php/TC

excurrent - $\quad$ stream, so it's called - not know, well

rather: to fall against finally

to: run to trickle beginning to spill over

pine choked till: deep in the lowland,

- the gullet, it's called - as: to be smuggled in

from the: spit- to the streambed - run-

off - exuded, mouthed out into

pitching flowing, fringes meandering

veins - towards: waterstop - cheekbone, now

gurgle and sticks stutters catches: on snares of

hornwort, toothed, flows in the: clearcut mouth 
http://ejournals.library.ualberta.ca/index.php/TC

\section{REFERENCES}

Benjamin, Walter. "The Task of the Translator." Trans. Harry Zohn. Selected Writings, Volume 1, 1913-1926. Ed. Marcus Bullock and Michael W. Jennings. Cambridge, MA: Harvard University Press, 1996.

Lefevere, André. "Mother Courage's Cucumbers: Text, System and Refraction in a Theory of Literature." The Translation Studies Reader. Second Edition. Ed. Lawrence Venuti. New York: Routledge, 2004: 239-255.

Spivak, Gayatri. "The Politics of Translation." The Translation Studies Reader. Second Edition. Ed. Lawrence Venuti. New York: Routledge, 2004: 369388.

---. "Translating into English." Nation, Language, and the Ethics of Translation. Ed. Sandra Bermann and Michael Wood. Princeton: Princeton UP, 2005: 93110.

Utler, Anja. münden - entzüngeln. Vienna: Edition Korrespondenzen, 2004.

Weber, Samuel. "A Touch of Translation: On Walter Benjamin's 'Task of the Translator."' Nation, Language, and the Ethics of Translation. Ed. Sandra Bermann and Michael Wood. Princeton: Princeton UP, 2005: 65-78.

(C) Copyrights TransculturAl \& Author (2009) 